\title{
Stanisław ZAKRZEWSKI
}

Uniwersytet im. Adama Mickiewicza, Poznań

\section{BEZPIECZEŃSTWO SOCJALNE A WYKLUCZENIE SPOLECZNE}

Zagrożenia bezpieczeństwa socjalnego nie są zjawiskiem nowym, charakterystycznym dla Polski współczesnej. Występowały w okresie międzywojennym i w czasach ustroju socjalistycznego. Wynikały przede wszystkim z utrzymujących się przez całe dziesięciolecia sfer niedostatku obejmujących rodziny wielodzietne, a także ze zmian jakie nastąpiły na rynku pracy, w tym przede wszystkim powstaniem i rozwojem bezrobocia. Osoby i rodziny, które do tej pory uzyskiwały dochody z pracy, czasem skromne, ale wystarczające na zaspokojenie podstawowych potrzeb o własnych siłach, tracąc pracę znalazły się w niespotykanej dotąd sytuacji niedostatku, braku środków na zaspokojenie elementarnych potrzeb, konieczności korzystania z pomocy socjalnej, a w pewnych sytuacjach nawet w sytuacji bezdomności. Paradoksalnie, nawet coraz lepszy dostęp do studiów, coraz większy odsetek dobrze wykształconych Polaków, co w końcu jest miarą postępu cywilizacyjnego, spowodował, iż dziś najważniejszym problemem absolwentów wyższych uczelni jest znalezienie, czasami jakiejkolwiek, pracy. W przypadku niektórych kierunków studiów, zwłaszcza humanistycznych, staje się to coraz trudniejsze. I z tych też powodów kwestia bezpieczeństwa socjalnego nabiera coraz większego znaczenia. Zapoczątkowana w Polsce w ostatniej dekadzie XX w. transformacja polityczna, gospodarcza i społeczna, wraz z pozytywnymi efektami w wielu dziedzinach życia, przyniosła także następstwa negatywne, także dla tych, których poczucie bezpieczeństwa nie było dotąd zagrożone. Jest to związane przede wszystkim z gwałtownymi zmianami.

W polityce społecznej poziom i sposób zaspokajania podstawowych potrzeb społecznych opisywany jest zazwyczaj za pomocą dwóch pojęć: „,bezpieczeństwo socjalne” i ,bezpieczeństwo społeczne”. W literaturze czasami te pojęcia używane są zamiennie. Zasadnym jednak wydaje się przyjąć - za Mirosławem Księżopolskim - iż mają one odmienne znaczenie. Autor ten bezpieczeństwo społeczne uznaje za pojęcie szersze, oznaczające ,... stan wolności od niedostatku materialnych środków utrzymania i istnienie realnych gwarancji pełnego rozwoju jednostek; obejmuje więc nie tylko stan wolności od ryzyk socjalnych, ale i od zagrożeń rozwoju psychospołecznego jednostki, których źródłem może być całokształt uwarunkowań społecznych, politycznych i ekonomicznych" . Natomiast bezpieczeństwo socjalne definiuje jako „stan wolności od zagrożeń, których skutkiem jest brak lub niedostatek środków utrzymania”. Przy czym,

${ }^{1}$ M. Księżopolski, Bezpieczeństwo socjalne, w: Leksykon polityki społecznej, red. B. Rysz-Kowalczyk, Warszawa 2001, s. 20. 
według cytowanego autora, zagrożeniami tymi są zagrożenia zaliczane do klasycznych ryzyk socjalnych (ryzyk ubezpieczeniowych w ubezpieczeniach społecznych), takie jak: choroba, wypadek przy pracy i choroba zawodowa, niepełnosprawność, starość, utrata pracy, macierzyństwo czy utrata żywiciela rodziny. Autor uściśla też, iż w pojęciu niedostatku środków utrzymania mieszczą się nie tylko środki pieniężne bądź rzeczowe, ale także brak odpowiedniej opieki wymaganej np. ze względu na stan zdrowia czy wiek ${ }^{2}$.

Nie do końca z takim rozumieniem bezpieczeństwa socjalnego zgadza się Ryszard Szarfenberg, uznając, że jest to definicja negatywna, a dopiero w definicji bezpieczeństwa społecznego pojawia się aspekt pozytywny (,,istnienie realnych gwarancji pełnego rozwoju jednostek"). Autor ten proponuje więc rozumienie bezpieczeństwa socjalnego jako ,istnienie realnych gwarancji minimalnie wystarczających środków utrzymania"3.

Z kolei Danuta M. Piekut-Brodzka, zwracając uwagę na cechy bezpieczeństwa socjalnego podkreśla, że jest ono tak kategorią, która odnosi się do przeżyć konkretnego człowieka, jak i kategorią rozpatrywaną w wymiarze społecznym. Traktując bezpieczeństwo socjalne jako odczucie osobnicze autorka stwierdza, iż: „Ludzie poszukują bezpieczeństwa socjalnego (we własnym jego rozumieniu), aby zaspokoić swoje potrzeby, usunąc egzystencjalne niepokoje. Cechą bezpieczeństwa socjalnego jest również to, że zazwyczaj wiąże się z zagrożeniem bezpośrednim i rzeczywistym. Należy i do sfery ducha i do sfery ciała, potrzeb niematerialnych i materialnych" .

Prezentując poglądy na temat rozumienia pojęcia ,bezpieczeństwo socjalne” warto zwrócić uwagę na koncepcje Niklasa Luhmanna, twórcy teorii ewolucji systemów politycznych nowoczesnych społeczeństw industrialnych i postindustrialnych. Zwraca on uwagę, iż określanie mianem państwa bezpieczeństwa socjalnego państwa, które określonym warstwom społecznym zapewnia szeroki zakres świadczeń socjalnych i z tego tytułu ponosi ogromne koszty, jest określeniem zbyt powierzchownym. Formułuje więc inną koncepcję państwa bezpieczeństwa socjalnego posługując się socjologiczną zasadą inkluzji, oznaczającą objęcie wszystkich członków społeczeństwa skutkami działania poszczególnych systemów funkcjonalnych. Zdaniem N. Luhmanna: „Realizacja zasady inkluzji w funkcjonalnej dziedzinie polityki prowadzi w konsekwencji do ukształtowania się państwa bezpieczeństwa socjalnego. Państwo bezpieczeństwa socjalnego urzeczywistnia inkluzję polityczną. Chodzi przy tym nie tylko o zabezpieczenie i stałe podnoszenie standardów minimum przysługujących każdemu warunków socjalnych, lecz także o różne szczególnego rodzaju problemy życiowe każdego, kto znajdzie się w trudnej sytuacji. Toteż nie tylko podnosi się poziom powszechnego minimum bytowego, ale podejmuje się coraz to nowe problemy jako zadania publiczne",5.

2 Ibidem

3 R. Szarfenberg, Bezpieczeństwo socjalne a wykluczenie społeczne, w: Bezpieczeństwo socjalne, red. L. Frąckiewicz, Katowice 2003, s. 86.

4 D. M. Piekut-Brodzka, Zwiqzki polityki społecznej i pracy socjalnej a bezpieczeństwo socjalne, w: Bezpieczeństwo socjalne, op. cit., s. 62.

${ }^{5}$ N. Luhmann, Teoria polityczna państwa bezpieczeństwa socjalnego, Warszawa 1994, s. 36-38. 
Nie ma najmniejszych wątpliwości, iż jedną z najważniejszych niematerialnych potrzeb ludzkich jest potrzeba bezpieczeństwa. Ma ona charakter wielowymiarowy i może występować na wielu płaszczyznach. Na płaszczyźnie najszerszej, globalnej rozumiana być może jako życie w regionie i kraju, gdzie nie występują zbrojne konflikty międzynarodowe. W nieco mniejszym wymiarze, to życie w kraju praworządnym, przyjaznym obywatelom. W skali lokalnej to np. zamieszkiwanie w spokojnej okolicy, bez obaw o zaczepki, napady, dewastacje czy kradzieże. W wymiarze osobistym to choćby wykonywanie pracy w bezpiecznych i higienicznych warunkach, pewność posiadania pracy, czy bezpieczny, w znaczeniu bezkonfliktowy dom, czy też pewność posiadania dachu nad głową. Przeciwieństwem poczucia bezpieczeństwa jest poczucie zagrożenia, obawa, iż własne możliwości, umiejętności czy zasoby mogą okazać się niewystarczające $w$ sytuacji niekorzystnych procesów czy wydarzeń zewnętrznych.

Jak stwierdza Anna Sowińska: „Sytuacja zagrożenia ekonomicznego wyznacza relacje jednostki z otoczeniem ekonomiczno-społecznym i jest równoznaczna z groźbą pogorszenia się sytuacji społecznej, obniżenia się poziomu życia, co oznacza ściśle z nim związane pogorszenie się jakości życia człowieka. Zagrożenie jest rozumiane jako prawdopodobieństwo utraty jakiejś cenionej przez jednostkę wartości (bytowania na określonym poziomie, pozycji społeczno-ekonomicznej itp.) $)^{6}$. Zdaniem cytowanej autorki do najpoważniejszych zagrożeń socjalnych należą: głód, bezdomność, długotrwałe bezrobocie, niemożność korzystania z pomocy medycznej w czasie choroby, brak zapewnienia środków i pomocy medycznej w czasie choroby, brak zapewnienia środków i pomocy (opieki) na starość. Powołuje się ona też na badania systematycznie prowadzone przez Centrum Badań Opinii Społecznej dotyczące poczucia zagrożenia i jego źródeł w społeczeństwie polskim. Wynika z nich, iż do najpoważniejszych przyczyn obaw na płaszczyźnie socjalnej Polacy zaliczają: materialne warunki życia, pracę i zdrowie, a więc zagrożenia determinujące brak poczucia bezpieczeństwa socjalnego ${ }^{7}$.

Istnieje wyraźny związek pomiędzy zjawiskami patologicznymi a bezpieczeństwem socjalnym. Nasilenie tych zjawisk bez najmniejszych wątpliwości i w sposób wyraźny wpływa na wzrost zagrożenia socjalnego. Nie oznacza to oczywiście, że dotyczy to w jednakowym stopniu wszystkich zjawisk z zakresu patologii społecznej. Największym zagrożeniem będą przede wszystkim takie, jak: bezrobocie, ubóstwo, bezdomność czy wykluczenie społeczne. Większego znaczenia dla poczucia bezpieczeństwa socjalnego nie muszą natomiast mieć także zaliczane do zjawisk patologicznych takie zjawiska, jak: piercing, zespół objadania nocnego, subkultura hip-hopowców czy tatuowanie.

Nie ulega najmniejszych wątpliwości, iż jednym z największych zagrożeń dla poziomu bezpieczeństwa socjalnego jest brak pracy. Bezrobocie, będąc samo w sobie zjawiskiem patologicznym, wywołuje kolejne takie zjawiska, jak choćby niedostatek, bezdomność, uzależnienia, a nawet samobójstwa. Truizmem jest stwierdzenie, iż pobudzenie gospodarki, a przez to zwiększenie liczby miejsc pracy, najskuteczniej ogranicza rozmiary bezrobocia. Jako, że nie zawsze jest to możliwe, poszukuje się nowych

6 A. Sowińska, Strategie zaradcze w sytuacjach utraty poczucia bezpieczeństwa socjalnego, w: Bezpieczeństwo socjalne, op. cit., s. 106.

Ibidem, s. 106-107. 
sposobów rozwiązania tego problemu. Jednym z nich jest wprowadzanie elastycznego rynku pracy i nietypowych form zatrudnienia. Choć z jednej strony może to spowodować zmniejszenie liczby osób pozostających bez pracy, to z drugiej wywołuje kolejne problemy. Przede wszystkim jest to kwestia znalezienia równowagi pomiędzy takim rynkiem (ang. flexbility) a bezpieczeństwem socjalnym (ang. social security). Polityka takiej równowagi określana jest mianem polityki flexcurity ${ }^{8}$.

Kolejnym problemem społecznym wpływającym na poziom bezpieczeństwa socjalnego dużych grup społecznych jest występujący od wielu lat w Polsce problem mieszkaniowy. Dotyczy on wielu rodzin i osób, w tym zwłaszcza osób młodych zakładających bądź myślących o założeniu rodziny, których nie stać na zakup własnego mieszkania. Problem mieszkaniowy od pewnego czasu pogłębia się, obejmując osoby i rodziny, które do tej pory miały ustabilizowaną sytuację mieszkaniową. Teraz jednak te mieszkania traca, bądź takim niebezpieczeństwem są realnie zagrożone. Jest to związane ze sprzedażą domów przez dotychczasowych właścicieli (w tym zwłaszcza przez zakłady pracy i inne instytucje), a także z odzyskiwaniem mieszkań znajdujących się w zasobach komunalnych przez dawnych właścicieli bądź ich spadkobierców. Często w bezwzględny sposób starają się oni pozbyć dotychczasowych lokatorów bądź poprzez drastyczne podniesienie wysokości czynszu, bądź też przez utrudnianie, a czasami wręcz uniemożliwianie normalnej egzystencji (uciążliwe, nie zawsze uzasadnione remonty, odcinanie mediów itd.). Pojawiły się wręcz nowe instytucje, określana potocznie jako „czyściciele kamienic”, które na zlecenie nowych właścicieli podejmują działanie, często na granicy prawa, a czasami wręcz bezprawne, mające na celu zmuszenie mieszkańców do wyprowadzki. Problem ten w przeważającej mierze dotyczy ludzi starszych, często schorowanych, którym sytuacja materialna nie pozwala na zakup nowego mieszkania.

Zarówno kwestia mieszkaniowa, jak i problem bezrobocia mają ścisły związek z kolejnym poważnym problemem społecznym, jakim jest wykluczenie społeczne. Kwestia grup i ludzi, którzy mają ograniczony dostęp do dóbr i usług powszechnie przysługujących społeczeństwu, jest różnie nazywany. Najczęściej określa się ją mianem wykluczenia społecznego, zamiennie ekskluzji społecznej. Zjawisko to określa się też jako marginalizację (marginalność) społeczną. Choć można uznać, iż pojęcia: wykluczenie społeczne i marginalizacja społeczna mają nieco odmienne znaczenie, zamienne ich stosowanie można uznać za zasadne, dotyczą bowiem tego samego zjawiska. Różnicy można się co najwyżej doszukiwać w głębokości tego zjawiska, w stopniu ograniczenia dostępu do dóbr i usług; w przypadku wykluczenia społecznego jest on zdecydowanie większy. Można by też uznać, iż wykluczenie społeczne jest skrajną postacią marginalizacji społecznej.

Zdefiniowanie wykluczenia społecznego nie jest łatwe, gdyż jest to zjawisko wielowymiarowe, składające się ze zróżnicowanych czynników. Oprócz tego może ono występować na wielu różnych poziomach funkcjonowania tak grup społecznych, jak i jednostek w ich skład wchodzących. Najogólniej wykluczenie społeczne można okre-

${ }^{8}$ M. Rymsza, W poszukiwaniu równowagi pomiędzy elastycznościq rynku pracy i bezpieczeństwem socjalnym. Polska $w$ drodze do flexcurity?, w: Elastyczny rynek pracy i bezpieczeństwo socjalne. Flexcurity po polsku?, red. M. Rymsza, Warszawa 2005, s. 12-13. 
ślić jako specyficzny proces alienacji grup społecznych. Dla procesu tego charakterystyczne są m.in. takie cechy, jak:

- niski poziom uczestnictwa w życiu społecznym;

- długotrwałość i niedobrowolność takiej sytuacji;

- ograniczenia możliwości korzystania z podstawowych praw obywatelskich.

Zdaniem Tadeusza Kowalaka na zjawisko marginalizacji społecznej składa się kilka, nakładających się na siebie wymiarów, a o wykluczeniu decyduje: „stopień, w jakim jednostka lub grupa społeczna pozbawiona jest władzy, uprawnień, możliwości wyboru dostępu do dóbr materialnych i kulturowych, możliwości wypoczynku. Decydującym może być fakt, że osoba taka jest do czegoś przymuszana, dyskryminowana, gdy jest bezradna i pozbawiona pomocy"'.

Wśród osób i grup wykluczonych, przez pozbawienie ich możliwości uczestniczenia w życiu społecznym, czy choćby ograniczenie takich możliwości lub na podstawie rezygnacji jednostki bądź grupy z niektórych obszarów uczestnictwa społecznego, można, jak stwierdza Anna Kotlarska-Michalska, wyróżnić takie kategorie marginalne jak: długotrwale bezrobotni, bezdomni, żebracy, pasywni życiowo, niepełnosprawni, najubożsi, osoby o odmiennych orientacjach seksualnych czy przestępcy. Jednakże, zdaniem cytowanej autorki, cztery kategorie społeczne: bezdomni, bezrobotni, niepełnosprawni oraz żebracy podlegają przede wszystkim procesowi marginalizacji w Polsce współczesnej ${ }^{10}$.

Wymieniony wyżej krąg osób szczególnie narażonych na wykluczenie społeczne w czasach współczesnych wzbogaca się o jeszcze inne przesłanki wykluczenia spowodowane mechanizmami ideologicznymi, etnicznymi, wyznaniowymi, a zwłaszcza informatycznymi ${ }^{11}$. Można wręcz mówić o wykluczeniu informatycznym, które może przejawiać się np. w braku dostępu do Internetu czy braku umiejętności pracy z komputerem. Za słuszne należy więc uznać stwierdzenie Małgorzaty Orłowskiej, iż cechą współczesnych czasów, związaną ze zjawiskiem wykluczenia społecznego jest to, że: „wykluczonym może być każdy z nas, w każdej chwili. Jednak w pierwszej kolejności są to ludzie szczególnie obarczeni jakąś dysfunkcją społeczną, fizyczną, psychiczną lub też nawet kilkoma naraz" ${ }^{\prime 2}$.

Chcąc opisać cechy grup i osób marginalizowanych społecznie, najlepiej posłużyć się katalogiem proponowanych przez socjologów kryteriów wyodrębnienia niżej wymienionych kategorii społecznych:

- bogatych, średnio zamożnych i biednych;

- odgrywających rolę aktorów oraz widzów przemian społecznych;

- uczciwych i oszukujących;

- zdolnych i niezdolnych do adaptacji;

- innowatorów i konformistów;

9 T. Kowalak, Marginalność i marginalizacja społeczna, Warszawa 1998, s. 27.

10 A. Kotlarska-Michalska, Nowe kategorie społeczne, w: Współczesne społeczeństwo polskie, red. R. Suchocka, Poznań 2002, s. 57-58.

11 E. Trafiałek, Marginalizacja ludzi starszych a dylematy polityki społecznej, w: Działania społeczne w pracy socjalnej na progu XXI wieku, red. E. Kantowicz, A. Olubiński, Torun 2003, s. 471.

12 M. Orłowska, Słowo wstęne, w: Skazani na wykluczenie, red. M. Orłowska, Warszawa 2005, s. 7. 
- wygranych i przegranych;

- optymistów, realistów i pesymistów;

- aktywnych i biernych zawodowo;

- aktywnych i biernych życiowo;

- zajmujących wysokie, średnie i niskie pozycje społeczne;

- zaradnych i niezaradnych;

- zyskujących i tracących;

- beneficjentów i przegrywających;

- akceptujących i nieakceptujących zmiany społeczne ${ }^{13}$.

Uwzględniając powyższe kryteria Anna Kotlarska-Michalska wyróżnia następujące kategorie jednostek marginalizowanych, żyjących poza strukturami społecznymi. Są to jednostki, które: 1) zaliczają się do biednych lub biedniejących; 2) grają bardziej rolę widzów przemian społecznych, niż role aktorów; 3) przejawiają brak zdolności do adaptacji; 4) częściej reprezentują postawę konformistyczną niż innowacyjną; 5) są w swej opinii przegrani; 6) reprezentują pesymistyczną postawę wobec życia; 7) częściej są bierni zawodowo i społecznie; 8) mają świadomość zajmowania niskich pozycji społecznych; 9) tworzą zbiorowości ludzi niezaradnych życiowo; 10) tracą w nowej rzeczywistości społecznej; 11) jednocześnie zaliczane są do kategorii osób przegrywających z nowymi regułami gry społecznej; 12) nie akceptują zmian społecznych, bowiem zmiany te przyczyniły się do spadku ich pozycji społecznej ${ }^{14}$.

W ustawie o pomocy społecznej ${ }^{15}$ wymieniono kategorie osób, którym bezwzględnie należy udzielić wsparcia. Są wśród nich między innymi: osoby niepełnosprawne, długotrwale bezrobotni, opuszczający zakłady karne, bezdomni, ubodzy, sieroty, przewlekle lub ciężko chorzy, bezradni w sprawach opiekuńczo-wychowawczych i prowadzenia gospodarstwa domowego, osoby będące imigrantami, mające trudności w integracji. Bez najmniejszych wątpliwości można stwierdzić, że są to osoby już wykluczone, bądź też bardzo poważnie zagrożone niebezpieczeństwem wykluczenia w najbliższej przyszłości. Całkiem słusznym wydaje się zatem stwierdzenie Dariusza Magierka, iż wykluczenie społeczne dotyczy przede wszystkim tych osób i rodzin, które:

- żyją w złych warunkach ekonomicznych (ubóstwo materialne);

- są ofiarami niekorzystnych procesów społecznych wynikających z masowych i dynamicznych zmian rozwojowych, takich np. jak: kryzysy, nagłe upadki branż bądź regionów;

- nie posiadają odpowiedniego kapitału życiowego, który umożliwiłby im właściwą pozycję społeczna, odpowiedni poziom kwalifikacji, wejście na rynek pracy, czy też założenie rodziny;

- nie posiadają dostępu (bądź też dostęp ten jest mocno ograniczony) do odpowiednich instytucji, umożliwiających inkluzję społeczną; może to być spowodowane niedorozwojem czy niewłaściwym funkcjonowaniem tych instytucji;

13 A. Kotlarska-Michalska, Nowe kategorie..., op. cit., s. 56.

14 A. Kotlarska-Michalska, Życie poza strukturami społecznymi jako efekt przemian społecznych $w$ Polsce, w: Współczesne społeczeństwo polskie. Przemiany struktury społecznej, red. R. Suchocka, Poznań 2005, s. 60.

15 Ustawa z dnia 12 marca 2004 roku o pomocy społecznej, Dz. U. 2013, poz. 182. 
- są ofiarami dyskryminacji ze względu na mankamenty ustawodawcze czy kulturowe uprzedzenia oraz stereotypy, czy też ze względu na niepełnosprawność bądź inne cechy indywidualne;

- są narażone na negatywne w skutkach działania innych osób, w postaci np. przemocy, szantażu, indoktrynacji ${ }^{16}$.

Ujmując marginalność jako pozycję społeczną grup odrzuconych na peryferie społeczne przez inne grupy w społeczeństwie o wertykalnej i hierarchicznej strukturze, F. Mahler wyodrębnia pewne, ogólne cechy grup wykluczonych. Należy zaliczyć do nich: pozbawienie władzy i dostępu do podejmowania decyzji, posiadanie przez takie grupy mniejszego zakresu uprawnień przy większym zakresie obowiązków, mniejsze możliwości wyboru, a więcej przymusu, mniejsze szanse i gorsze sytuacje ekonomiczne, niższe możliwości zdobywania lepszego wykształcenia, umiejętności zawodowych, wypoczynku itd., wyższą podatność na nacisk społeczny i na kryzysy, dyskryminacyjne traktowanie przez obowiązujące prawo, napiętnowanie i dyskryminowanie ${ }^{17}$.

Kwestia tego, czy dana osoba jest wykluczona, czy też nie, wynika z jej uczestnictwa w stosunkach społecznych. Jeżeli w tym uczestnictwie zauważa się bariery i ograniczenia, a dana osoba, bądź też grupa zajmuje wyraźnie gorszą pozycję, niż pozostała część społeczeństwa, mamy do czynienia z wykluczeniem społecznym. Aby zidentyfikować marginalność konkretnej osoby, bądź grupy osób, należy, jak stwierdza Bożena Chrostowska, ustalić obszar, jakiego ono dotyczy:

1) kto, co jest marginalne (zasięg terytorialny lub społeczny)? W tym przypadku chodzi o ustalenie pewnych cech identyfikacyjnych z grupy tzw. socjodemograficznych, np. wiek, płeć, kolor skóry, wyznawana religia, a także pozbawienie władzy, dostępu do podejmowania decyzji, wszelkiego rodzaju dyskryminacji;

2) czego dana osoba bądź grupa jest pozbawiona (przedmiot)? Chodzi tu o ustalenie, o jakie należne jej uprawnienia chodzi, z których obszarów jest wyłączona. Takimi obszarami mogą być np. rynek pracy, uczestnictwo w oświacie i szkolnictwie wyższym, w życiu kulturalnym, dostęp do świadczeń społecznych, udział w mechanizmach demokratycznych (wybory, referenda, konsultacje społeczne);

3) do jakiego stopnia dana osoba czy grupa osób pozbawiona jest uprawnień (głębokość)? W tym przypadku podejmuje się działania, których celem jest ustalenie stopnia braku uczestnictwa, co ma kluczowe znaczenie w zakwalifikowaniu danej osoby, czy też grupy osób do kategorii społecznie wykluczonych. Szczególnie ważne jest to, iż „określenie stopnia braku uczestnictwa będącego jednocześnie granica, poniżej której zaczyna się marginalność, zależy od uwarunkowań środowiskowych ${ }^{18}$.

W ostatnich latach problematyka wykluczenia społecznego zajmuje coraz bardziej istotne miejsce w programach i praktycznych działaniach Unii Europejskiej. Jeszcze w podpisanym w 1992 r. traktacie z Maastricht, wśród podstawowych praw, które zostały zagwarantowane obywatelom państw należących do Unii, znalazły się przede

${ }^{16}$ D. Magierek, Polityka społeczna w Strategii Lizbońskiej, w: Europejska polityka społeczna, red. R. Gabryszak, D. Magierek, Warszawa 2011, s. 175.

17 Za: B. Chrostowska, Marginalizacja społeczna i jej identyfikacja, w: Działania społeczne..., op. cit., s. $213-214$.

18 Ibidem, s. 216. 
wszystkim prawa polityczne, natomiast prawa społeczne, w tym także te zapobiegające marginalizacji społecznej, zostały pominięte. Rozwiązanie takie spotkało się jednak z powszechną krytyką płynącą niemal ze wszystkich wspólnotowych państw. W jej rezultacie już po czterech latach, a mianowicie w 1996 r. w Turynie, dokonano rewizji traktatu, uzupełniając go o kwestie socjalne, w tym przede wszystkim takie jak ubóstwo, bezrobocie, zagadnienia związane z kryzysem państwa socjalnego, a przede wszystkim o problematykę wykluczenia społecznego ${ }^{19}$. W realizowanej przez Unię Europejską w pierwszej dekadzie XXI w. Strategii lizbońskiej uznano już, iż walka z ubóstwem i wykluczeniem społecznym jest jednym z głównych zobowiązań Unii Europejskiej i jej państw członkowskich wobec obywateli. Stwierdzono, iż poziom ubóstwa i wykluczenia społecznego osiagnął takie rozmiary, iż stał się nie do zaakceptowania. Z kolei w przyjętej na drugą dekadę XXI w. Strategii Europa 2020 sformułowano trzy nadrzędne priorytety składające się na wizję konkurencyjnej społecznej gospodarki rynkowej XXI w. Wśród nich, obok inteligentnego rozwoju i rozwoju zrównoważonego, znalazł się rozwój sprzyjający społecznemu włączeniu. W 2008 r. na mocy decyzji 1098/2008/WE Parlamentu Europejskiego i Rady Unii Europejskiej proklamowano rok 2010 Europejskim Rokiem Walki z Ubóstwem i Wykluczeniem Społecznym. W dokumencie tym stwierdzono, iż: ,... znaczna część mieszkańców wciąż cierpi na skutek niedostatku lub ograniczonego i nierównego dostępu do usług lub jest wykluczona ze społeczeństwa”, a wykluczenie społeczne: „zagraża pomyślności obywateli, ograniczając ich możliwości wyrażania poglądów i aktywnego udziału w życiu społecznym" "20. Podkreślając, że ubóstwo i wykluczenie społeczne to problem szeroki, różnorodny i wieloaspektowy, powiązany z ,z wieloma czynnikami, takimi, jak: dochody i poziom życia, możliwości kształcenia się i odpowiedniego zatrudnienia, skuteczne systemy opieki socjalnej, warunki mieszkaniowe, dostęp do dobrych jakościowo usług zdrowotnych i innych usług oraz aktywne obywatelstwo"21, za priorytet uznano: „wzmocnienie spójności społecznej oraz wyeliminowanie problemu ubóstwa i wykluczenia społecznego, ${ }^{, 2}$. W decyzji zwrócono uwagę, że: „W krajowych programach działań na rzecz integracji społecznej wiele państw członkowskich podkreśla wysokie zagrożenie ubóstwem lub wykluczeniem społecznym szczególnych grup, w tym dzieci, osób wcześnie kończących naukę, rodziców samotnie wychowujących dzieci, dużych rodzin, rodzin mających jedynego żywiciela, ludzi młodych, zwłaszcza młodych kobiet, osób starszych, migrantów i mniejszości etnicznych, osób niepełnosprawnych i ich opiekunów, bezdomnych, bezrobotnych, a zwłaszcza osób długoterminowo bezrobotnych, więźniów, kobiet i dzieci będących ofiarami przemocy oraz

19 E. Trafiałek, Marginalizacja ludzi starszych a dylematy polityki społecznej, op. cit., s. 472.

20 Pkt 7 i 10, Preambuła, Decyzja Parlamentu Europejskiego i Rady Nr 1098/2008/WE z 22 października 2008 r. w sprawie Europejskiego Roku Walki z Ubóstwem i Wykluczeniem Społecznym (2010), Dziennik Urzędowy UE L 298, 7.11.2008.

21 Pkt 13, Preambuła, Decyzja Parlamentu Europejskiego i Rady Nr 1098/2008/WE z 22 października 2008 r. w sprawie Europejskiego Roku Walki z Ubóstwem i Wykluczeniem Społecznym (2010), op. cit.

22 Pkt 11, Preambuła, Decyzja Parlamentu Europejskiego i Rady Nr 1098/2008/WE z 22 października 2008 r. w sprawie Europejskiego Roku Walki z Ubóstwem i Wykluczeniem Społecznym (2010), op. cit. 
narkomanów"23. Za niezbędne uznano uzyskanie poparcia szerokich kręgów społecznych i wsparcia politycznego. Stwierdzono, iż najważniejszym celem i zasadą przewodnią Europejskiego Roku Walki z Ubóstwem i Wykluczeniem Społecznym, obok wspólnej odpowiedzialności i uczestnictwa, spójności, zaangażowania i konkretnych działań, będzie: „uznanie praw - uznanie podstawowego prawa osób dotkniętych ubóstwem i wykluczeniem społecznym do godnego życia i do pełnego uczestnictwa w życiu społeczeństwa" ${ }^{24}$.

Najważniejszym mechanizmem finansowym dbającym o rozwój i wspierającym europejską politykę społeczna, jest utworzony jeszcze w 1957 r., na mocy traktatu rzymskiego, Europejski Fundusz Społeczny. Ma on za zadanie poprawę sytuacji na rynku pracy, zapewnienie możliwości w zakresie swobodnego przesiedlania się pracowników na terenie Wspólnoty, zmiany zawodu i podnoszenia kompetencji zawodowych. Utworzony w ramach funduszu Program Operacyjny Kapitał Ludzki koncentruje swoje działania m.in. na kwestii integracji społecznej i przeciwdziałaniu wykluczeniu społecznemu. Programy wsparcia obejmują przede wszystkim osoby „zagrożone wykluczeniem społecznym ze szczególnym uwzględnieniem osób korzystających długotrwale ze świadczeń pomocy społecznej" ${ }^{\prime 25}$. Chodzi więc o osoby bezrobotne powyżej 24 miesięcy, alkoholików i narkomanów, którzy poddają się procesowi leczenia lub ukończyli go nie później niż rok przed przystapieniem do projektu, a także o bezdomnych, o osoby opuszczające zakłady karne najpóźniej rok przed przystapieniem do projektu. Pomocą objęci są również uchodźcy z problemami z integracją ze społeczeństwem oraz młodzież wychowywana w placówkach opiekuńczo-wychowawczych i rodzinach zastępczych. Z programów wsparcia korzystać mogą także: „osoby w wieku 12-24 lat, które: nie uczą się, nie pracują i nie są zarejestrowane jako bezrobotne, uczą się w szkołach gimnazjalnych albo w formach pozaszkolnych, ale sprawiają trudności wychowawcze i mają poważne kłopoty $\mathrm{w}$ nauce, pochodzące $\mathrm{z}$ rodzin ubogich, zagrożonych dysfunkcjami społecznymi lub wchodzące w kolizję z prawem"26.

Zauważenie przez Unię Europejską kwestii wykluczenia społecznego i uznanie jej za jedno z najważniejszych wyzwań stwarza dobrą płaszczyznę do efektywnej walki z tym patologicznym zjawiskiem. Wyraźne zmniejszenie liczby grup i osób marginalizowanych będzie jednak możliwe dopiero wtedy, kiedy zostaną podjęte skuteczne działania na czterech podstawowych płaszczyznach. Po pierwsze - jest to ograniczenie sfer ubóstwa i niedostatku. Po drugie - zmniejszenie bezrobocia. Po trzecie - eliminowanie z obowiązującego prawa wszelkich zapisów stwarzających możliwość dyskryminacji i wykluczenia społecznego. Po czwarte wreszcie - umacnianie solidaryzmu społecznego i zwiększenie stopnia integracji społecznej. Systematyczne i skuteczne działania na tych wszystkich płaszczyznach bez wątpliwości pozwolą na ograniczenie

${ }^{23}$ Pkt 16, Preambuła, Decyzja Parlamentu Europejskiego i Rady Nr 1098/2008/WE z 22 października 2008 r. w sprawie Europejskiego Roku Walki z Ubóstwem i Wykluczeniem Społecznym (2010), op. cit.

24 Art. 2, Decyzja Parlamentu Europejskiego i Rady Nr 1098/2008/WE z 22 października 2008 r. w sprawie Europejskiego Roku Walki z Ubóstwem i Wykluczeniem Społecznym (2010), op. cit.

25 M. Gogacka, Rola Europejskiego Funduszu Społecznego w przeciwdziałaniu wykluczeniu społecznemu, w: Od wykluczenia do elity. Jakość życia, red. R. Derbis, Częstochowa 2008, s. 413.

${ }^{26}$ Ibidem. 
liczby osób i grup marginalizowanych i - dzięki temu - na zwiększenie poczucia bezpieczeństwa społecznego obywateli państw Unii Europejskiej.

\title{
STRESZCZENIE
}

Wśród niematerialnych potrzeb ludzkich do najważniejszych, z punktu widzenia polityki społecznej, należy potrzeba bezpieczeństwa. Stąd takim istotnym problemem jest gwarantowanie obywatelom poczucia bezpieczeństwa socjalnego. Choć z jednej strony, rozwój gospodarczy przynosi za sobą wzrost zamożności społeczeństwa, a co za tym idzie, wzrost poczucia bezpieczeństwa socjalnego, z drugiej strony w społeczeństwie nadal występują osoby i grupy, które, z różnych powodów, nie korzystają z owoców owego postępu. Dotyczy to zwłaszcza tych, którzy mają ograniczony dostęp do podstawowych dóbr i usług powszechnie przysługujących. Ta kategoria osób - to osoby wykluczone, czy też marginalizowane społecznie. Dla wykluczenia społecznego najbardziej charakterystyczne są trzy cechy: niski poziom uczestnictwa w życiu społecznym, długotrwałość i niedobrowolność takiej sytuacji, ograniczenie możliwości korzystania z podstawowych praw obywatelskich. Kwestia wykluczenia społecznego od niedawna została uznana przez Unię Europejską za jeden z podstawowych problemów społecznych. Stąd ogłoszenie roku 2010 Europejskim Rokiem Walki z Ubóstwem $i$ Wykluczeniem Spotecznym i podjęcie konkretnych działań w celu ograniczenia tych zjawisk. Daje to nadzieję, że tak w Unii Europejskiej, jak i w Polsce uda się zmniejszyć ilościowe rozmiary wykluczenia społecznego.

\section{SOCIETAL SECURITY AND SOCIAL EXCLUSION}

\begin{abstract}
Among the nonmaterial human needs, the most important, from the point of view of social policy, is the need for security. Thus, the important issue is to guarantee citizens a sense of social security. Though on one hand, economic development brings an increase in wealth of society, and thus, an increased sense of social security, on the other hand, in society, there are still individuals and groups who, for various reasons, do not take advantage of the fruits of that progress. This applies especially to those, who have limited access to basic goods and services which are commonly available. This category of people are those, who are excluded or socially marginalized. There are three most characteristic features for social exclusion: a low level of participation in social life, long duration and non-voluntary state of such condition, restricting possibilities of use of basic civil rights. The issue of social exclusion has recently been recognized by the European Union as one of the main social problems. Hence the announcement of 2010 as the European Year for Combating Poverty and Social Exclusion and taking concrete actions to reduce these phenomena. This gives hope that in the European Union as well as in Poland, quantitative dimensions of social exclusion can be reduced.
\end{abstract}

